\title{
Pengaruh Kompensasi Terhadap Disiplin Kerja Karyawan Pada PT. Strategic Pestcontrol Tebet Jakarta Selatan
}

\author{
Bachtiar Arifudin Husain \\ Dosen Fakultas Ekonomi Universitas Pamulang \\ Email : dosen01773@unpam.ac.id
}

\begin{abstract}
ABSTRAK
Tujuan dari penelitian ini adalah untuk mengetahui bagaimana kompensasi dan disiplin kerja karyawan Pada PT. Strategic Pestcontrol Tebet Jakarta Selatan, serta untuk mengetahui apakah terdapat pengaruh antara kompensasi terhadap disiplin kerja karyawan Pada PT. Strategic Pestcontrol Tebet Jakarta Selatan.

Metode penelitian yang digunakan dalam penelitian ini adalah Deskriptif Asosiatif dengan pendekatan kuantitatif, yaitu dengan mendeskripsikan keadaan responden serta deskripsi variabel penelitian dalam tabel frekuensi dan presentase dari hasil penyebaran kuesioner tersebut dengan melalui prosedur analisis data. Populasi dalam penelitian ini sebanyak 57 orang dan jumlah sampel sebanyak 57 orang dengan menggunakan sampel jenuh. Teknik analisis data menggunakan uji validitas, uji reliabilitas, regresi linier sederhana, koefisien korelasi, koefisien determinasi dan uji signifikansi (uji t).

Hasil penelitian menunjukan bahwa kompensasi dan disiplin kerja karyawan saat ini sudah baik. Nilai koefisien regresi variabel kompensasi terhadap disiplin kerja adalah sebesar 0,896. Hal ini berarti jika kompensasi naik 1 satuan maka akan meningkatkan disiplin kerja sebesar 0,896. Korelasi Product Moment didapat nilai $\mathrm{r}_{\mathrm{xy}}$ sebesar 0,915 yang artinya terdapat hubungan positif yang sangat kuat antara kompensasi dengan disiplin kerja karyawan pada PT. Strategic Pestcontrol. Hasil dari koefisien determinasi sebesar 0,837. Hal ini menunjukan bahwa sebesar 83,7\% kompensasi memiliki kontibusi pengaruh terhadap disiplin kerja, sedangkan sisanya sebesar $16,3 \%$ dipengaruhi oleh variabel lain yang tidak diteliti dalam penelitian ini. Dan besarnya nilai $t_{\text {hitung }}>t_{t a b e l}$, yaitu $16,830>2,004$, nilai probabilitas (signifikansi) $=0.000$ yaitu berada di bawah 0.050 dengan demikian dapat disimpulkan bahwa terdapat pengaruh yang positif dan signifikan variabel kompensasi terhadap disiplin kerja karyawan pada PT. Strategic Pestcontrol.
\end{abstract}

\section{Kata kunci : Kompensasi dan Disiplin Kerja}




\section{PENDAHULUAN}

Sumber daya manusia merupakan faktor yang sangat menentukan dalam menjalankan aktifitas organisasi guna mencapai tujuan yang diinginkan. Untuk itu perlu adanya manajemen sumber daya manusia yang memperhatikan perencanaan, pengorganisasian strategi, pengawasan dan pengendalian yang baik agar fungsi dan sistem manajemen dapat berjalan dengan baik.

Disiplin kerja sangatlah penting dan menjadi tolak ukur untuk mengukur atau mengetahui apakah fungsi manajemen sumber daya manusia lainnya secara keseluruhan telah dilaksanakan dengan baik atau tidak, disiplin kerja yang baik, mencerminkan bahwa fungsi-fungsi manajemen sumber daya manusia lainnya telah dilaksanakan sesuai dengan rencana.

Menurut Hasibuan (2009:193), kedisiplinan adalah kesadaran dan kesediaan seseorang menaati semua peraturan perusahaan dan normanorma sosial yang berlaku. Kesadaran itu sendiri merupakan sikap seseorang yang secara sukaela menaati semua peraturan dan sadar akan tugas dan tanggung jawabnya. Sehingga karyawan akan menaati dan mematuhi peraturan yang dibuat dengan baik bukan atas paksaan yang berlaku. Sedangkan kesadaran itu sendiri ialah suatu sikap, tingkah laku, dan perbuatan seseorang yang sesuai dengan peraturan perushaan, baik yang tertulis maupun tidak.

Menurut Simamora (2014:442) kompensasi adalah semua bentuk kembalian finansial, jasa-jasa terwujud dan tunjangan yang di peroleh karyawan sebagai bagian dari hubungan kekaryawanan. Singodimedjo dalam Sutrisno (2009:94), kompensasi adalah semua balas jasa yang diterima seorang karyawan dari perusahaannya sebagai akibat dari jasa atau tenaga yang telah diberikannya pada perusahaan. Dessler (2009:125), kompensasi adalah setiap imbalan yang diberikan kepada karyawan dan timbul dari dipekerjakannya karyawan itu. Meskipun dalam praktiknya kinerja seseorang itu berbeda-beda antara satu dengan yang lainnya, namun kompensasi yang diberikan dengan bentuk uang atau barang adalah sarana untuk memenuhi kebutuhan mereka. Kompensasi yang akan diterima oleh mereka merupakan cermin dari apa yang telah mereka berikan atau kerjakan kepada organisasi atau perusahaan. Dengan memberikan kompensasi yang dilaksanakan secara benar dapat memuaskan dan memotivasi karyawan guna mencapai tujuan organisasi atau perusahaan.

Menurut Handoko (2009:30) bahwa faktor pendorong penting yang menyebabkan manusia bekerja adalah adanya kebutuhan dalam diri manusia yang harus dipenuhi. Dengan kata lain, berangkat dari keinginan untuk memenuhi kebutuhan hidup, manusia bekerja dengan menjual tenaga, pikiran dan juga waktu yang dimilikinya kepada perusahaan dengan harapan mendapatkan kompensasi (imbalan). Sebuah organisasi atau perusahaan untuk mencapai sebuah tujuannya bergantung pada kinerja pegawai. Maka dari itu, dengan memberikan kompensasi atas kinerja para pegawai akan memberikan timbal balik 
kontribusi untuk kelangsungan hidup pada organisasi atau perusahaan.

Demikian juga dengan PT. Strategic Pestcontrol merupakan sebuah perusahaan yang bergerak dibidang jasa pengendalian hama yang meliputi perumahan, perkantoran, gudang, hotel, apartemen, dan lain sebagainya. Adapun permasalahan yang terjadi pada perusahan tersebut diantaranya adalah masih banyak karyawan yang

\section{Tabel 1}

Data Absensi Karyawan PT. Strategic Pestcontrol Tahun 2014-2016

\begin{tabular}{|c|c|c|c|c|c|c|}
\hline Tahun & Jumlah karyawan & I & S & A & Jumlah & Persentase Ketidakhadiran \\
\hline 2014 & 57 & 26 & 31 & 22 & 79 & $32,9 \%$ \\
\hline 2015 & 57 & 31 & 27 & 25 & 83 & $34,5 \%$ \\
\hline 2016 & 57 & 35 & 42 & 27 & 104 & $43,3 \%$ \\
\hline
\end{tabular}

Sumber : HRD PT. Strategic Pestcontrol

Dari tabel 1di atas, dapat terlihat dengan jelas bahwa tingkat absensi karyawan sangat tinggi di atas ketentuan perusahaan yaitu $10 \%$. Tingkat absensi karyawan mengalami kenaikan dari tahun 2014 sampai 2016. Pada tahun 2014 tingkat absensi sebesar 32,9\%, di tahun 2015 mengalami kenaikan sebesar $1,6 \%$ menjadi $34,5 \%$ dan di tahun 2016 terjadi peningkatan lagi sebesar $8,8 \%$ menjadi 43,3\%. Hal ini jika dibiarkan dalam jangka panjang maka akan berdampak pada kinerja perusahaan.

Data kompensasi yang diterima karyawan pada PT. Strategic Pestcontrol dapat dilihat pada tabel 2 berikut ini :

\section{Tabel 2}

Data Kompensasi Karyawan PT. Strategic Pestcontrol

\begin{tabular}{|c|c|}
\hline $\begin{array}{c}\text { Gaji Karyawan } \\
\text { Perbulan }\end{array}$ & $\begin{array}{c}\text { Rp. 2.000.000- } \\
3.000 .000\end{array}$ \\
\hline Insentif & Tidak Ada \\
\hline Bonus & Tidak Ada \\
\hline THR & $\begin{array}{c}\text { Kurang dari satu kali } \\
\text { gaji }\end{array}$ \\
\hline \multicolumn{2}{|c|}{ HRD PT. Strategic Pestcontrol }
\end{tabular}

HRD PT. Strategic Pestcontrol tidak disiplin dalam bekerja, kinerja karyawan belum optimal, karyawan tidak merasa puas dengan besaran kompensasi yang diterima, gaya kepemimpinan dirasakan terlalu acuh, semangat kerja menurun, masih banyak karyawan yang terlambat masuk kerja dan sepertinya sulit untuk mendapatkan promosi jabatan. Ketidakdisiplinan karyawan dapat dilihat pada tabel 1 berikut ini :
Dari tabel 2 di atas, penulis melihat adanya permasalahan pada gaji yang diterima karyawan masih dibawah Upah Minimum Regional (UMR). UMR jakarta 2017 sebesar Rp.3.355.750. Namun gaji karyawan PT. Strategic Pestcontrol berkisar antara Rp. 2.000.000-3.000.000. Selain permasalahan gaji, insentif dan bonus seringkali dikeluhkan karyawan karena tidak adaya pemberian insentif dan bonus dari perusahaan, dan juga THR yang didapat oleh karyawan besarannya kurang dari satu kali gaji. Hal ini jika dibiarkan dalam jangka panjang maka akan berdampak pada disiplin kerja karyawan yang akhirnya berdampak pada kinerja perusahaan.

\section{METODE PENELITIAN}

\section{Teknik Analisis Data}

Dalam penelitian ini, metode analisis data yang digunakan adalah analisis data kuantitatif. Analisis data kuantitatif mempunyai ciri dapat dinilai dengan angka. 
Metode analisis data yang digunakan dalam penelitian ini meliputi:

\section{Uji Validitas}

Validitas instrumen dalam penelitian ini ditentukan dengan mengorelasikan antara skor yang diperoleh setiap butir penyataan dengan skor total. Dimana skor total adalah jumlah dari semua skor pernyataan.

\section{Uji Reliabilitas}

Metode yang digunakan dalam penelitian ini untuk menghitung reliabilitas instrumen yaitu dengan menggunakan metode Cronbach Alpha.

Dimana rumus yang digunakan adalah sebagai berikut:

$$
r_{c a}=\left[\frac{k}{k-1}\right]\left[1-\frac{\sum S i}{\sum S t}\right]
$$

\section{Analisis Korelasi Sederhana}

Menurut Anwar (2012:122), fungsi utama dari analisis korelasi adalah untuk menentukan seberapa erat hubungan antara variabel satu dengan lainnya. Analisis korelasi dalam penelitian ini untuk mengetahui seberapa besar hubungan antara variabel bebas yaitu kompensasi dan variabel terikat yaitu disiplin kerja karyawan. Rumus yang digunakan untuk menghitung korelasi antara variabel bebas dengan variabel terikat adalah Korelasi Product Moment.

\section{Analisis Regresi Linier Sederhana}

Fungsi utama dari analisis koefisien regresi merupakan cerminan atau yang menggambar ada tidaknya pengaruh variabel bebas terhadap variabel terikat.
Salah satu model yang paling gampang untuk menjelaskan pengaruh itu adalah regresi linier sederhana, yaitu $\mathbf{y}^{\prime}=\mathbf{a}+\mathbf{b x}$

\section{Analisis Koefisien Determinasi}

Tujuan analisis koefisien determinasi adalah untuk mengetahui seberapa besar pengaruh antara variabel bebas $(\boldsymbol{x})$ dan variabel terikat $(\boldsymbol{y})$ dalam persen (\%). Adapun tujuan analisis determinasi dalam penelitian ini adalah untuk mengetahui pengaruh antara variabel kompensasi dan variabel disiplin kerja karyawan dalam persen (\%). Rumus yang digunakan dalam analisis koefisien determinasi yaitu:

$$
\boldsymbol{K D}=\left(\boldsymbol{r}_{\boldsymbol{x} y)}\right)^{2} \times 100 \%
$$

\section{Uji Hipotesis}

Untuk memperkuat hasil perhitungan yang diperoleh dan untuk mengetahui tingkat signifikasi pengaruh antara variabel bebas $(\boldsymbol{x})$ dengan variabel terikat (y) maka dilakuan uji hipotesis dengan langkah-langkah sebagai berikut:

a. Merumuskan hipotesis

Adapun hipotesis yang diajukan dalam penelitian ini adalah sebagai berikut:

$\boldsymbol{H o}: \boldsymbol{r}_{\boldsymbol{x} \boldsymbol{y}}=\mathbf{0}$ Tidak ada pengaruh yang positif dan signifikan antara kompensasi terhadap disiplin kerja karyawan pada PT. Strategic Pestcontrol.

$\boldsymbol{H a}: \boldsymbol{r}_{\boldsymbol{x} y} \neq \mathbf{0}$ Adanya pengaruh yang positif dan signifikan antara kompensasi terhadap disiplin kerja karyawan pada PT. Strategic 
Pestcontrol.

b. Uji Signifikasi

Untuk dapat mengetahui pengaruh yang signifikasi antara variabel bebas $(\boldsymbol{x})$ dengan variabel terikat $(\boldsymbol{y})$ maka perlu dilakukan uji signifikasi korelasi dengan mengunakan uji- $\boldsymbol{t}$ dengan rumus:

$$
t_{\text {hitung }}=\frac{r_{x y} \sqrt{n-2}}{\sqrt{1-r_{x y}^{2}}}
$$

Dimana:

$\boldsymbol{t}_{\text {hitung }}=$ Nilai $\mathrm{t}$ hitung yang selanjutnya

dibandingkan dengan nilai $\boldsymbol{t}_{\text {tabel }}$

$$
\begin{aligned}
& \boldsymbol{r}_{\boldsymbol{x} \boldsymbol{y}}=\text { Nilai } \quad \text { koefisien } \\
& \text { korelasi antara } \\
& \text { variabel bebas }
\end{aligned}
$$

$(\boldsymbol{x})$ dengan variabel terikat $(\boldsymbol{y})$

$$
\boldsymbol{n} \quad \underset{\text { (responden) }}{\text { Jumlah }} \text { sampel }
$$

c. Tingkat signifikasi

Selanjutnya, nilai $\boldsymbol{t}_{\text {hitung }}$

dibandingkan dengan

$\boldsymbol{t}_{\text {tabel }}$ pada tingkat alfa (taraf kesalahan) $5 \%$ dengan derajat bebas (n-2).

Kriteria keputusan:

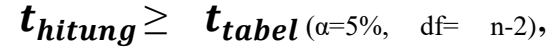
maka $\mathrm{Ho}$ ditolak dan $\mathrm{Ha}$ diterima

$\boldsymbol{t}_{\text {hitung }}<\boldsymbol{t}_{\text {tabel }(\alpha=5 \%, \quad \mathrm{df}=\quad \mathrm{n}-2),}$ maka $\mathrm{Ho}$ diterima dan $\mathrm{Ha}$ ditolak

\section{HASIL PENELITIAN PEMBAHASAN \\ 1. Analisis Regresi Linear

\begin{tabular}{|c|c|c|c|}
\hline \multirow[b]{2}{*}{ Model } & \multicolumn{2}{|c|}{$\begin{array}{l}\text { Unstandardi } \\
\text { zed } \\
\text { Coefficients }\end{array}$} & \multirow{2}{*}{$\begin{array}{c}\begin{array}{c}\text { Standardiz } \\
\text { ed } \\
\text { Coefficien } \\
\text { ts }\end{array} \\
\text { Beta }\end{array}$} \\
\hline & $\mathrm{B}$ & $\begin{array}{l}\text { Std. } \\
\text { Error }\end{array}$ & \\
\hline $1 \quad$ (Constant $)$ & $\begin{array}{c}7.81 \\
2\end{array}$ & 4.394 & \\
\hline $\begin{array}{c}\text { KOMPENS } \\
\text { ASI }\end{array}$ & .896 & .053 & .915 \\
\hline
\end{tabular} Sederhana}

Tabel 3

Uji Regresi Variabel Kompensasi Terhadap Disiplin Kerja Coefficients $^{\mathrm{a}}$

a. Dependent Variable: DISIPLIN_KERJA Sumber : Pengolahan Data SPSS versi 22, 2018.

Berdasarkan tabel 3 di atas, maka persamaan regresi linear sederhananya adalah sebagai berikut :

$$
\mathrm{Y}=7,812+0,896 \mathrm{x}
$$

Berdasarkan hasil perhitungan di atas dapat dijelaskan sebagai berikut :

1) Nilai konstanta intersep sebesar 7,812, merupakan konstanta (a). Menyatakan bahwa kalau $\mathrm{X}=0$, maka nilai $\mathrm{Y}=7,812$.

2) Nilai koefisien regresi variabel Kompensasi (X) terhadap Disiplin Kerja (Y) adalah sebesar 0,896. Hal ini berarti jika Kompensasi (X) naik 1 satuan maka akan meningkatkan Disiplin Kerja (Y) sebesar 0,896.

\section{Korelasi Product Moment}

Dalam menganalisis hubungan variabel $\mathrm{X}$ terhadap variabel Y pada PT. Strategic Pestcontrol, penulis menggunakan metode korelasi sederhana. Rumus yang digunakan untuk menghitung korelasi antara variabel bebas (X) dengan variabel terikat (Y) adalah Korelasi Product Moment. 
Tabel 4

Hubungan Variabel X Terhadap Y

\begin{tabular}{|c|c|}
\hline Model & $\mathbf{R}$ \\
\hline $\mathbf{1}$ & $\mathbf{, 9 1 5}^{\mathbf{a}}$ \\
\hline
\end{tabular}

a. Predictors: (Constant),Kompensasi Sumber : Pengolahan Data SPSS versi 22, 2018.

Berdasarkan tabel 4 di atas dengan menggunakan Korelasi Product Moment didapat nilai $\mathrm{r}_{\mathrm{xy}}$ sebesar 0,915 yang artinya terdapat hubungan positif yang sangat kuat antara Kompensasi (X) dengan Disiplin Kerja (Y) karyawan pada PT. Strategic Pestcontrol.

\section{Koefisien Determinasi}

Untuk mengetahui besar presentase kontribusi antara Kompensasi (X) terhadap Disiplin Kerja (Y) karyawan pada PT. Strategic Pestcontrol diukur dengan koefisien determinasi atau koefisien penentu dengan rumus sebagai berikut:

$$
\begin{aligned}
\mathrm{KD} & =\mathrm{r}^{2} \times 100 \% \\
& =0,915^{2} \times 100 \% \\
& =0,837 \times 100 \% \\
& =83,7 \%
\end{aligned}
$$

Tabel 5

\begin{tabular}{|c|c|c|c|c|}
\hline $\begin{array}{l}\text { Mode } \\
1\end{array}$ & $\mathrm{R}$ & $\begin{array}{c}\mathrm{R} \\
\text { Squar } \\
\mathrm{e}\end{array}$ & $\begin{array}{c}\text { Adjuste } \\
\text { d R } \\
\text { Square }\end{array}$ & $\begin{array}{l}\text { Std. } \\
\text { Error of } \\
\text { the } \\
\text { Estimat } \\
\text { e }\end{array}$ \\
\hline 1 & $\begin{array}{r}.915 \\
\mathrm{a}\end{array}$ & .837 & .834 & 2.961 \\
\hline
\end{tabular}

Uji Determinasi Variabel $\mathrm{X}$ terhadap $Y$

Model Summary

a. Predictors: (Constant), KOMPENSASI

Sumber : Pengolahan Data SPSS versi 22, 2018.

Hasil dari nilai $\mathrm{R}^{2}$ ( $\mathrm{R}$ Square) sebesar 0,837. Hal ini menunjukan bahwa sebesar $83,7 \%$ Kompensasi
(X) memiliki kontibusi pengaruh terhadap Disiplin Kerja (Y), sedangkan sisanya sebesar $16,3 \%$ dipengaruhi oleh variabel lain yang tidak diteliti dalam penelitian ini.

\section{Uji T}

\begin{tabular}{|c|c|c|c|}
\hline & Model & $\mathrm{T}$ & Sig. \\
\hline & (Constant) & 1.778 & .081 \\
\hline & $\begin{array}{c}\text { KOMPEN } \\
\text { SASI }\end{array}$ & 16.830 & .000 \\
\hline
\end{tabular}

Tabel 7

Uji T Variabel X terhadap Y Coefficients $^{\mathrm{a}}$

a. Dependent Variable:

DISIPLIN_KERJA

Sumber : Pengolahan Data SPSS versi 22, 2018.

Nilai $t_{\text {hitung }}$ sebesar 16,830, sedangkan nilai $t_{\text {tabel }}$ adalah sebesar 2,004. Jadi karena nilai thitung $>$ $t_{\text {tabel, }}$ yaitu 16,830 > 2,004, dengan nilai probabilitas (signifikansi) $=$ 0.000 yaitu berada di bawah 0.050 maka dapat disimpulkan bahwa terdapat pengaruh yang positif dan signifikan variabel Kompensasi (X) terhadap Disiplin Kerja (Y) karyawan pada PT. Strategic Pestcontrol.

\section{KESIMPULAN}

\section{A. Kesimpulan}

Berdasarkan hasil penelitian dan analisis data yang dilakukan dalam penelitian ini mengenai pengaruh kompensasi terhadap disiplin kerja karyawan pada PT. Strategic Pestcontrol Tebet Jakarta Selatan, maka penulis menyimpulkan sebagai berikut :

1. Kompensasi karyawan pada PT. Strategic Pestcontrol Tebet 
Jakarta Selatan saat ini sudah baik. Penulis menyimpulkan berdasarkan hasil jawaban seluruh responden yang berjumlah 57 orang dengan 10 pernyataan, sebanyak 28,07\%, responden menjawab" Sangat Setuju" dan sebanyak 59,12\% responden menjawab "Setuju" $=87,19 \%$.

2. Disiplin kerja karyawan pada PT. Strategic Pestcontrol Tebet Jakarta Selatan saat ini sudah baik. Penulis menyimpulkan berdasarkan hasil jawaban seluruh responden yang berjumlah 57 orang dengan 20 pernyataan, sebanyak 23,86\% responden menjawab "Sangat Setuju" dan 65,44\% responden menjawab "Setuju" $=89,3 \%$.

3. Dari hasil penelitian, penulis menyimpulkan adanya pengaruh yang positif dan signifikan antara kompensasi terhadap disiplin kerja karyawan pada PT. Strategic Pestcontrol Tebet Jakarta Selatan, hal ini didasarkan dari perhitungan analisis regresi sederhana sebesar 0,896 , hal ini berarti jika kompensasi naik 1 satuan maka akan meningkatkan disiplin kerja karyawan sebesar 0,896. Korelasi dibuktikan dengan rxy sebesar 0,915 yang berarti terdapat hubungan yang sangat kuat antara kompensasi dengan disiplin kerja dan koefisien determinasi sebesar $83,7 \%$, sementara sisanya sebesar $16,3 \%$ dipengaruhi oleh faktor lain yang tidak diteliti. Hasil uji hipotesis diperoleh $t_{\text {hitung }}$ $(16,830)>t_{\text {tabel }}(2,004)$, dengan nilai probabilitas (signifikansi) $=0.000$ yaitu berada di bawah 0.050, hal ini menunjukan bahwa kompensasi berpengaruh positif dan signifikan terhadap disiplin kerja karyawan pada PT. Strategic Pestcontrol Tebet Jakarta Selatan.

\section{B. Saran}

Berdasarkan hasil penelitian, maka penulis memberikan saran yang diharapkan bermanfaat bagi perusahaan, antara lain sebagai berikut:

1. Berdasarkan hasil kuesioner variabel kompensasi, responden menjawab tidak setuju dan sangat tidak setuju terbanyak pada pernyataan nomor 10 yaitu sebesar $8,77 \%$ terkait kebijakan perusahaan saat ini. Berdasarkan hal tersebut, PT. Strategic Pestcontrol Tebet Jakarta Selatan disarankan untuk meninjau kembali kebijakankebijakan perusahaan saat ini apakah sudah sesuai dengan prinsip keadilan bagi seluruh karyawan.

2. Berdasarkan hasil kuesioner variabel disiplin kerja, responden menjawab tidak setuju dan sangat tidak setuju terbanyak pada pernyataan nomor 20 yaitu sebesar 33,32\% terkait keharmonisan. Berdasarkan hal tersebut, karyawan disarankan untuk selalu menjaga keharmonisan sesama karyawan lainnya.

3. Apabila perusahaan meningkatkan konpensasi kepada karyawan maka 
karyawan dapat meningkatkan disiplin kerjanya.

\section{DAFTAR PUSTAKA}

Abdullah, Ma'aruf. Manajemen dan Evaluasi Kinerja Karyawan. Yogyakarta : Aswanda Pressindo. 2014.

Abdul, Muhid. Analisis Statistik. Sidoarjo : Zifatama. 2012.

Anwar. Eksipien Dalam Sediaan Farmasi Karakterisasi dan Aplikasi. Jakarta : Dian Rakyat. 2012.

Cascio, W. Managing Human Resources, Productivity, Quality of Work Life, Profits. Ninth Edition. America : The MacGraw Hill Company. 2013.

Danang Sunyoto. Dasar-dasar manajemen pemasaran. Yogyakarta : CAPS. 2012.

Gibson, James L., John M. Ivancevich, James H. Donnelly, Jr., and Robert Konopaske. Organizations: Behavior, Structure, Processes, Fourteenth Edition. New York : McGraw-Hill. 2012.

Hamalik, Oemar. Kurikulum dan Pembelajaran. Jakarta : PT. Bumi Aksara. 2008.

Hasibuan, Malayu. Manajemen Sumber Daya Manusia. Jakarta : Bumi Aksara. 2013.

Idrus, Muhammad. Metode Penelitian Ilmu Sosial. Yogyakarta : Erlangga. 2009.

Kaswan. Manajemen Sumber Daya Manusia untuk Keunggulan Bersaing Organisasi. Jakarta : Graha Ilmu. 2012.

Mangkunegara, Anwar Prabu. Manajemen Sumber Daya Manusia Perusahaan. Bandung : PT. Remaja Rosdakarya. 2013
Mathis Robert L. dan Jackson John H. Human Resource Management. Alih Bahasa. Jakarta : Salemba Empat. 2006.

Rialmi, Z., \& Morsen, M. (2020). Pengaruh Komunikasi Terhadap Kinerja Karyawan PT Utama Metal Abadi. JENIUS, 3(2), 221-227.

Rialmi, Z. (2017). Pengaruh Keadilan Prosedural Yang Diterapkan Kepemimpinan Pegawai Dan Kepuasan Kerja Pegawai Terhadap Kinerja Dari Pegawai BPBD Provinsi Riau. Jurnal Mandiri: Ilmu Pengetahuan, Seni, dan Teknologi, 1(2), 353374.

Rivai, Veithzal. Manajemen Sumber Daya Manusia Untuk Perusahaan Dari Teori Ke Praktek. Jakarta : Rajagrafindo Persada. 2011.

Robbins, Stephen P \& Coulter, Mary. Manajemen Edisi Kesepuluh. Jakarta : Erlangga. 2010.

Sinambela, Lijan. Kinerja Pegawai : Teori, Pengukuran dan Implikasi. Yogyakarta : Graha Ilmu. 2012.

Siswanto, Bedjo Sastrohadiwiryo. Memahami Penelitian Kualitatif. Bandung : Alfabeta. 2012.

Sugiyono. Metode Penelitian Pendidikan Pendekatan Kuantitatif, Kualitatif, dan $R \& D$. Bandung : Alfabeta. 2013.

Sulistiyani, Ambar Teguh dan Rosidah. Manajemen Sumber Daya Manusia. Konsep, Teori dan Pengembangan dalam Konteks Organisasai Publik, Edisi kedua. Yogyakarta : Graha Ilmu. 2009. 
Sunarsi, D. (2018). Pengaruh Kompensasi, Komunikasi Dan Stress Kerja Terhadap Prestasi Kerja Karyawan Pada PT Catur Putra Jaya Kota Depok-Jawa Barat. JIMF (Jurnal Ilmiah Manajemen Forkamma), 1(2).

Sunarsi, D. (2020). Panduan Meningkatkan Kinerja Dan Kepuasan Guru. Kota Serang: Desanta Muliavisitama

Sunarsi, D. (2019). Seminar Sumber Daya Manusia. Tangerang Selatan: Unpam Press

Sunarsi, D. (2018). Buku Ajar: Seminar Perencanaan Sumber Daya Manusia. Tangerang Selatan: Asmoro Mediatama
Sutrisno, Edy. Manajemen Sumber Daya Manusia, Cetakan Kelima. Yogyakarta : Prenada Media. 2013.

Suwatno. \& Priansa. Manajemen SDM dalam organisasi Publik dan Bisnis. Bandung : Alfabeta. 2011.

T. Hani, Handoko. Manajemen Pemasaran-Analisis Perilaku. Konsumen. Yogyakarta : BPFE. 2011.

Wibowo. Manajemen Kinerja. Jakarta : Raja Grafindo Persada. 2014.

Wirawan. Evaluasi Kinerja Sumberdaya Manusia,Teori Aplikasi dan Penelitian. Jakarta : Salemba Empat. 2012. 